Session 2566

\title{
INTEGRATED CURRICULUM DESIGN IN MECHANICAL ENGINEERING - OPPORTUNITIES AND CHALLENGES
}

\author{
SWAMI KARUNAMOORTHY and K. RAVINDRA \\ Department of Aerospace and Mechanical Engineering \\ Parks College of Engineering and Aviation \\ Saint Louis University
}

\begin{abstract}
The undergraduate engineering curriculum around the nation is being modified to meet the needs of the next century; to prepare the students to accept the challenges of a new century, and to satisfy the guidelines of ABET 2000 - the new criteria for accreditation. Mechanical engineering is the widest of all engineering disciplines. The reengineering of engineering curriculum gives an excellent opportunity to introduce new courses and to integrate multidisciplinary topics. However, the challenges are to give an adequate exposure in appropriate areas in the discipline and to minimize the number of credits. An emphasis is given in this paper to optimize the number of credits and to integrate the various aspects of mechanical engineering in the undergraduate curriculum at Parks College of Engineering \& Aviation at Saint Louis University.
\end{abstract}

\section{INTRODUCTION}

After the Second World War, we had industrial revolution. Now, due to the global economical changes, we have industrial reorganization. The role of an engineer has been redefined due to various changes in industries. Integration has gained importance and the concept of Integrated Product Development (IPD) has become the current industrial practice. The feed back from industrial peers and alumni has helped to reshape or modify the academic practices and the result is the Integrated Curriculum Design (ICD). The industrial peers can effectively contribute to the program through Industrial Advisory Committee (IAC). The Industrial Advisory Committee has been established for the continuos improvement of the Mechanical Engineering program at Parks College of Engineering. The input from the industrial committee and alumni are considered as important feedback to the system as shown in Figure 1.

In the beginning of this century, engineering curriculum was focused on training and learning of various skills. After the world war, the focus shifted to engineering science and the emphasis was on education and knowledge. Now, the focus is on a balanced combination of education and training to acquire the necessary skills and knowledge in Mechanical Engineering. In order to prepare the next generation of engineers with such attributes, the Accreditation Board for Engineering \& Technology has developed a new set of guidelines with outcome-based assessment, exposure to current industry practices and integration of design across the curriculum. 


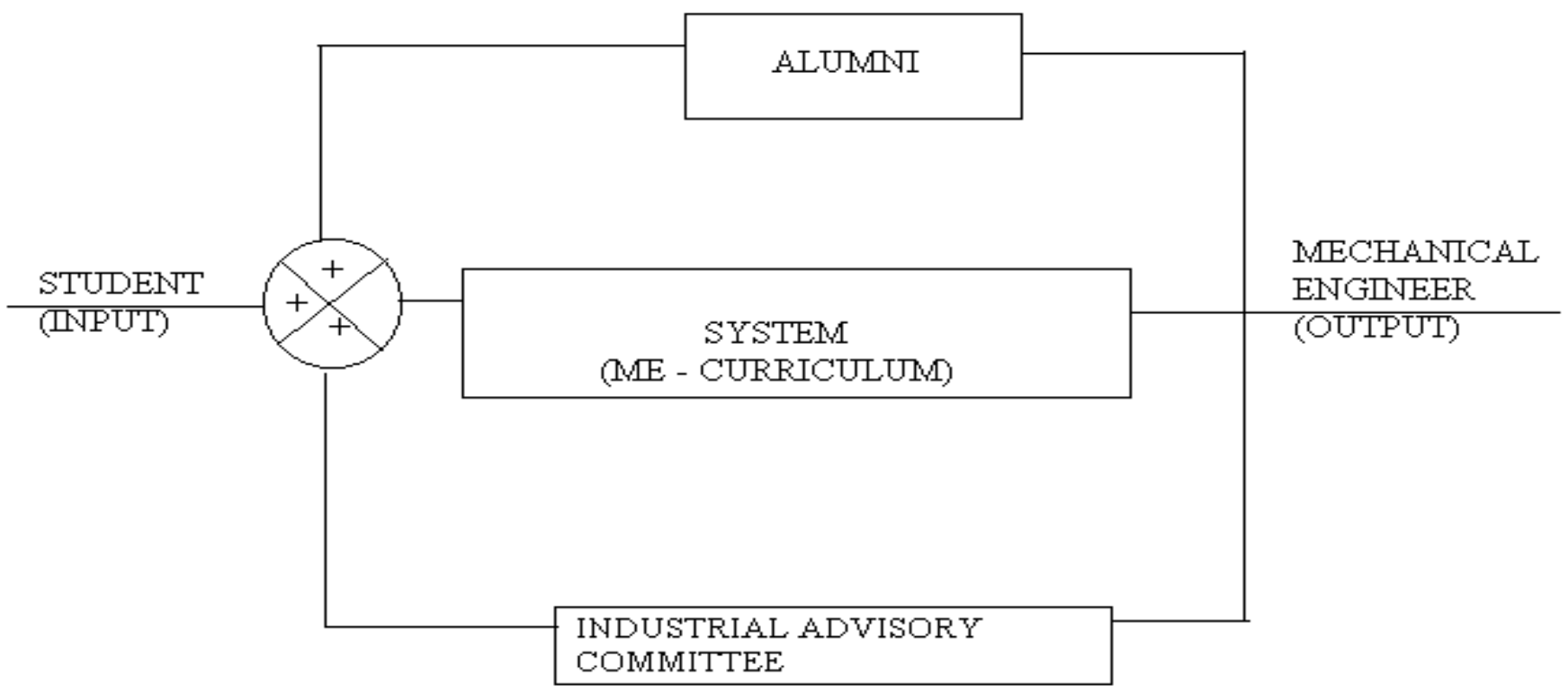

Figure 1 Continuous Improvement of Curriculum

In this paper, a description is given about the new curriculum in Mechanical Engineering at Parks College of Engineering \& Aviation. The opportunities and challenges are discussed with an emphasis on exposure to all the important topics. The curriculum has been carefully designed by optimizing the number of credits and number of courses.

\section{CURRICULUM}

The curriculum consists of courses from Humanities \& Social Sciences, Basic Sciences, Mathematics, Engineering Sciences, and Mechanical Engineering Major with an optimized load of 129 credits.

HUMANITIES \& SOCIAL SCIENCES: (18 credits)

$\begin{array}{ll}\text { Humanities } & 3 \mathrm{cr} . \\ \text { Social Science } & 3 \mathrm{cr} . \\ \text { Cultural diversity } & 3 \mathrm{cr} . \\ \text { Theology } & 3 \mathrm{cr} . \\ \text { Ethics } & 3 \mathrm{cr} . \\ \text { Engineering Ethics } & 3 \mathrm{cr} .\end{array}$

SKILL COURSES: (4 credits) Advance writing $3 \mathrm{cr}$. (Written communication skill) Small Group Presentation $1 \mathrm{cr}$. (Oral communication skill) 
BASIC SCIENCE: (14 credits)

Chemistry / Lab

$4 \mathrm{cr}$.

Physics I / Lab

5 cr. (Calculus Based)

Physics II / Lab

5 cr. (Calculus Based)

MATHEMATICS: (18 credits)

Calculus I

$4 \mathrm{cr}$.

Calculus II $4 \mathrm{cr}$.

Calculus III $4 \mathrm{cr}$.

Differential Equations $3 \mathrm{cr}$.

Advanced Mathematics $3 \mathrm{cr}$.

ENGINEERING SCIENCE: (34 credits)

Computer Science $3 \mathrm{cr}$.

Freshmen Engineering $4 \mathrm{cr}$.

Statics $3 \mathrm{cr}$.

Dynamics $3 \mathrm{cr}$.

Solid Mechanics / Lab 4 cr.

Fluid Dynamics $3 \mathrm{cr}$.

Thermodynamics $3 \mathrm{cr}$.

Linear Vibrations $3 \mathrm{cr}$.

Linear Systems $3 \mathrm{cr}$.

Electrical Eng. / Lab 5 cr.

ME MAJOR: (41 credits)

Foundation to Eng. Design $3 \mathrm{cr}$.

Kinematics $3 \mathrm{cr}$.

Machine Design $3 \mathrm{cr}$.

Material Science $3 \mathrm{cr}$.

Measurements $3 \mathrm{cr}$.

Manufacturing $3 \mathrm{cr}$.

Mechatronics $3 \mathrm{cr}$.

Applied Thermodynamics $3 \mathrm{cr}$.

Heat Transfer $3 \mathrm{cr}$.

Design I \& II $6 \mathrm{cr}$.

ME Laboratory $2 \mathrm{cr}$.

Technical Electives $6 \mathrm{cr}$.

TOTAL CURRICULUM CREDITS: 129

The flow chart with courses organized for each semester is given in the appendix. However, the integration of different components of education across the curriculum is given below.

STRUCTURES \& MOTION STEM

Freshmen: Freshmen Engineering (Introduction)

Sophomore: Statics \& Dynamics (Engineering Mechanics) 
Junior: Mechanics of Solids, Kinematics, Linear Vibrations

Senior: Analysis and Control of Linear systems

ENERGY STEM

Freshmen: Freshmen Engineering (Introduction)

Sophomore: Thermodynamics

Junior: Applied Thermodynamics, Fluid Dynamics

Senior: Heat transfer

MATERIALS, MEASUREMENTS \& MANUFACTURING

Freshmen: Freshmen Engineering, Physics

Sophomore: Physics, Foundation to Engineering Design

Junior: Material Science, Measurements, Machine Design, Mechanics of Solids Lab

Senior: Manufacturing Process, M.E. Lab., Mechatronics, Capstone Design

ELECTRICAL SCIENCE

Freshmen: Freshmen Engineering (Introduction)

Sophomore: Electrical Engineering / Lab

Junior: Measurements

Senior: Principles of Mechatronics (Multi-Disciplinary course)

STATISTICS \& PROBABILITY

Freshmen: Freshmen Engineering I \& II

Sophomore: Foundation to Engineering Design

Junior: Mechanics of Solids Lab, Machine Design, Measurements

Senior: ME Lab

\section{DESIGN PRINCIPLES}

Freshmen: Freshmen Engineering I \& II

Sophomore: Foundation to Engineering Design, Statics

Junior: Kinematics, Mechanics of Solids, Applied Thermodynamics, Fluid Dynamics, Machine Design.

Senior: Capstone Design I \& II, Heat Transfer, Principles of Mechatronics, Linear System

LABORATORY EXPERIENCE

Freshmen: Chemistry, Physics I, Freshmen Engineering

Sophomore: Physics II, Electrical Engineering

Junior: Mechanics of Solids

Senior: Mechanical Eng. Lab (Energy \& Structures), Manufacturing Process, Mechatronics.

COMPUTER SKILLS

Freshmen: Solid Modeling (Pro-E), Math Cad, Word Processing, C-language

Sophomore: Math Cad, Word Processing

Junior: Motion simulation (pro-mechanica), Application of advanced programming language.

Senior: Matlab, Pro-E, CAM, Programming with Microprocessor 


\section{OPPORTUNITIES AND CHALLENGES}

In the freshmen year the opportunities include, the introduction of Freshman Engineering course that replaces the conventional graphics course that existed in the previous curriculum. This course has two parts, offered one per semester with two credits each. The course contents include graphics, introduction to some software's (Math Cad, Microsoft Word, Internet etc.), introduction to engineering, and freshmen engineering design. The challenge is to team teach this class with multiple sections. Two-dimensional graphics (CADKEY) has been replaced by three-dimensional solid modeling (PRO-E). In the design part, the emphasis is on conceptual design and embodiment design with an exposure to brain storming and mind (or concept) mapping skills. The conventional Fortran programming course in the old curriculum replaced by a Computer science course with $\boldsymbol{C}$ language. The conventional Calculus courses have been modified with applications of Math-Cad computer software. The writing course on English includes the application of a word-processing software.

In the sophomore year, the communication skill is introduced by a course on Group Presentation with the application of Power Point software. Creative design (open-ended) problems are introduced in the Statics course in an innovative way. The design philosophy of synthesis and analysis are introduced in the course on Foundation to Engineering Design. The design problem sponsored by the ASME for student design contest has been included as integral part of this course. The principles of design for manufacturability (DFM), simplicity, cost optimization, and teamwork are emphasized.

In the junior year, design has been well integrated in Mechanics of Solids, Kinematics, Applied Thermodynamics, and Machine Design courses. Material selection and Measurement techniques for testing are introduced to add strength to the component of education in design. Similar to Statics, the courses on Mechanics of Solids and Applied Thermodynamics include open ended problems. In the Mechanics of Solids Laboratory course, an emphasis is given to introduce the various aspects of Probability and Statistics. In Kinematics, a design project has been included as an integral part of the course. The objective is to find a linkage-based solution to the design problem. In Machine design, an emphasis is given to the design of mechanical components or machine elements. The design process also includes design for strength, design for stiffness, material selection and failure criteria. A course in Materials Science gives an exposure to conventional, modern, and smart materials while a course on Measurements introduces various topics on sensors and transducers. The measurement course also integrates some topics on the application of Probability and Statistics.

In the senior year, design is an integral part of most of the engineering courses. In addition, a sequence of two capstone design courses are included. The capstone design courses include industry sponsored design problems with a peer from industry as design consultant. An exposure is given to the core of design principles that include Need Establishment, Abstraction, Synthesis, Analysis, Evaluation (of alternate design), and Implementation. Also, an exposure is given to various topics on Manufacturing methods. A new course on Principles of Mechatronics has been included to introduce the modern control of mechanical systems with microprocessor based digital control system. This course also includes the design component through a project on Mechatronic system design. 
Two technical elective courses provide an opportunity to introduce the modern and current topics of interest in Mechanical Engineering. The humanities courses satisfy the University core requirement as well as ABET requirement. Also, a sequence of courses on Ethics and Engineering Ethics provide the depth in the area of Ethics or Philosophy. The oral and written communication skills are integrated through various laboratory reports, term papers, project presentations, and design presentations.

\section{OUTCOME BASED EDUCATION}

The notion of outcome based assessment leads to the concept of outcome based education. The present curriculum has been carefully designed such that we can answer two important questions. They are, (i) What is the outcome in terms of education and training we expect from a student at the time of graduation, and (ii) What are the Primary traits or the core of knowledge we expect in student's learning at the time of completing each course. It may be called as Primary Trait Paradigm (PTP). It is a viable concept and it provides a great opportunity for outcome based assessment. The challenge lies in the implementation process. It requires changes in course perspectives, style of teaching, and assessment methods.

The goal of each course is written to reflect the principles of PTP, which changes the course perspective. It almost serves as a frame to an existing picture. The teaching style is aimed at satisfying these goals. The assessment methods are directed to pedagogical significance rather than statistical significance. Now, the emphasis is shifted from the evaluation of performance to assessing the deficiency in student's learning, which is a paradigm shift.

\section{CONCLUSIONS}

The academic curriculum has always been continuously evolving to meet the needs of our society. Now is the time for a curriculum that is well balanced with education and training to provide the necessary knowledge and skills; a curriculum that has vertical integration of design and other engineering principles; a curriculum that is outcome based with an emphasis on Primary Trait Paradigm. The periodic feedback from the Industrial Advisory Committee helps to fine tune the curriculum. The committee also serves as a source for outcome based assessment and be aware of the current industrial practice. Such a curriculum would be viable and challenging for the future-graduating engineers as we step into the next decade, a new century.

\section{ACKNOWLEDGEMENT}

The valuable inputs and suggestions of all the faculty in the department of Aerospace and Mechanical Engineering at Parks College of Engineering \& Aviation, is greatly appreciated and acknowledged. The constructive criticism and ideas of the Industrial Advisory Committee members are gratefully acknowledged. 


\section{REFERENCES}

1. Shaeiwitz J.A. et.al., "The Holistic Curriculum", Journal of Engineering Education, Vol.83, 1994, pp. 343-348.

2. Karunamoorthy S., "Problem Workshop - A Viable Concept for Design Integration", 1994, ASEE Annual Conference Proceedings, American Society for Engineering Education.

3. Anand D.K. et.al., "A Mechanical Engineering Curriculum for the Next Decade", 1995, ASEE Annual Conference Proceedings.

4. Hodge B.K. and Steel W.G., "Experience with a Curriculum with Balanced Design Contents in all Stems", 1995, ASEE Annual Conference Proceedings.

5. Criteria for Accrediting Programs in Engineering in the United States, Effective for two year period beginning in January 1996, ABET, 1995.

6. Karunamoorthy S. et.al., "A Symbiotic Relationship of Design Integration, Design Space, and Design Optimization", Proceedings of the Fourth Specialized Conference on Operations Research and Engineering Design, 1995.

7. Shaeiwitz J. A., "Outcomes Assessment in Engineering Education", Journal of Engineering Education, Vol.85, No.3, 1996, pp.239-246.

8. Nagy P. and Cameron T., "Re-Engineering the Engineering Curriculum", 1997 ASEE Section Conference Proceedings, Illinois/Indiana. 


\section{APPENDIX: M.E. - FLOW CHART}

Parks College of Engineering \& Aviation

Department of Aerospace \& Mechanical Engineering

\section{FRESHMEN YEAR}

\section{Semester 1}

Engineering Chemistry ................. 3

Engineering Chemistry Lab ............ 1

Advanced Writing for Professionals .... 3

Freshmen Engineering I .............. 2

Engineering Calculus I ................ 4

Humanities ......................... $\underline{3}$

16

\section{SOPHOMORE YEAR}

\section{Semester 3}

Small Group Presentation.............. 1

Statics .............................. . 3

Engineering Calculus III .............. 4

Engineering Physics II ............... 4

Engineering Physics II Lab ........... 1

Theological Foundation .............. $\quad \underline{3}$

\section{6}

JUNIOR YEAR

\section{Semester 5}

Mechanics of Solids

Mechanics of Solids Lab

Applied Thermodynamics

Kinematics

Fluid Dynamics

Advanced Mathematics for Engineers..

\section{Semester 7}

Design I

Manufacturing Process .................

Mechanical Engineering Lab ......... $\quad 2$

Linear Systems .......................

Principles of Mechatronics ...........

Engineering Ethics ................ $\underline{3}$

17
Semester 2

Freshmen Engineering II ........... 2

Computer Science ................... 3

Engineering Calculus II ............. 4

Engineering Physics I .............. 4

Engineering Physics I Lab .......... 1

Social/Behavioral Science .......... $\quad \underline{3}$

Semester 4

Foundation to Engineering Design ... 3

Electrical Engineering ................. 4

Electrical Engineering Lab........... 1

Dynamics .......................... 3

Differential Equations ............... 3

Thermodynamics .................. $\underline{3}$

Semester 6

Material Science ................... 3

Machine Design ................... 3

Measurements ..................... 3

Linear Vibrations .................. 3

Ethics .......................... $\underline{3}$

SENIOR YEAR

Semester 8

Design II ........................ 3

Heat Transfer ..................... 3

Cultural Diversity ................. 3

Technical Electives ................ 6

Total hours required for graduation: 129 